\title{
Modern Theory of Capital Cost and Capital Structure by Brusov- Filatova-Orekhova (BFO Theory) for Companies, which Ceased to Exist at the Time Moment $\mathbf{n}$
}

\author{
P.N. Brusov ${ }^{1,}$, T.V. Filatova ${ }^{2}$, N.P. Orekhova ${ }^{3}$, M.A. Eskindarov ${ }^{4}$ and V.L. Kulik ${ }^{5}$ \\ ${ }^{1}$ Applied Mathematics Department, Financial University under the Government of Russian Federation, \\ Moscow, Russia \\ ${ }^{2}$ Dean, Public Administration and Municipal Management Faculty, Financial University under the Government \\ of Russian Federation, Moscow, Russia \\ ${ }^{3}$ High Business School, Southern Federal University; Corporate Finance, Investment and Taxation \\ Laboratory, Research Consortium of Universities of the South of Russia, Rostov-on-Don, Russia \\ ${ }^{4}$ Rector, Financial University under the Government of Russian Federation, Moscow, Russia \\ ${ }^{5}$ Management Department, Financial University under the Government of Russian Federation, Moscow, \\ Russia
}

\begin{abstract}
Modern theory of capital cost and capital structure by Brusov-Filatova-Orekhova (BFO theory), which describes the companies of arbitrary age $\mathrm{n}$ in opposite to the perpetuity Modigliani - Miller theory, is applied for companies, which ceased to exist at the time moment $\mathrm{n}$. The required modification of BFO theory has been done in the paper. Formula BFO-2 for calculation of dependences of weighted average cost of capital, WACC, on the company's of lifetime $n$, on leverage level $L$ and on tax on profit rate $t$ for companies, which ceased to exist at the time moment $n$ has been derived. We analyze these dependences and compare them with the results of classical BFO theory which describes the companies of arbitrary age $n$. Comparing of results, obtained for companies as remaining in the market (BFO), as well as retired from the market (BFO-2) shows that dependence of the weighted average cost of capital WACC of companies on leverage level $L$, the company's lifetime (or age) $n$ and the tax on profit rate $t$ are qualitatively similar in nature, while, there are significant quantitative differences in these dependences: WACC for companies ceased to exist, always turns out to be higher than that of the companies that remain on the market (with the same parameters: leverage level $\mathrm{L}$, the company's lifetime (or age) $\mathrm{n}$ and the tax on profit rate $\mathrm{t}$, capital costs (equity and debt)), by other words the cost of attracting capital for companies that continue to operate, is always lower.
\end{abstract}

We examine whether the effects, discovered by us within classical BFO theory, are present in its modified form (BFO-2). We have found that within trade off theory there is no an optimal capital structure for BFO-2 case as well as for BFO (as it has been proven by us before), while the qualitatively new effect in corporative finance (decreasing of equity cost $k_{e}$ with leverage L), existing within classical BFO theory, is absent in BFO-2 case similar to the case of perpetuity companies.

Keywords: Classical BFO theory, BFO theory modified for companies, which ceased to exist.

\section{INTRODUCTION}

First quantitative theory of capital cost and capital structure by Modigliani - Miller (Modigliani et al. 1958; 1963 ; 1966) can be applied to perpetuity companies, i.e. to companies with infinite lifetime or infinitely old. In this (perpetuity) case there is no any difference between infinitely old companies and companies with infinite lifetime. In case of finite time $n$, introduced by BFO authors (Brusov et al. 2015; 2011a,b,c,d,e; 2012 a,b; 2013 a,b,c; 2014 a,b; Filatova et al. 2008), there is an important difference between companies of the age $n$ (1) and companies with the lifetime $n$ (2).

In the (1) case companies have reached the age of n-years and continue to exist on the market, while in

*Address correspondence to this author at the Applied Mathematics Department, Financial University under the Government of Russian Federation, Moscow, Russia; Tel: +7-928-1901445; Fax: +7-928-1901445;

E-mail: pnb1983@yahoo.com the case (2) the companies ceased to exist at time moment $n$, i.e. for them $n$ means not age, but a life time, i.e. the time of existence.

From the output of the classical BFO formula it follows, that developed ideology is applied to companies which have reached the age of $n$-years and continue to exist on the market, by other words, BFO is applicable to the most interesting case of companies reached the age of $n$-years and continue to exist on the market, so BFO allows to analyze the financial conditions of the operating companies (Brusov et al. 2015; 2011a,b,c,d,e; 2012 a,b; 2013 a,b,c; 2014 a,b; Filatova et al. 2008). But for some purposes (for business valuation, anti-crises management and other fields) it could be sometimes useful to investigate the companies, which ceased to exist at the time moment $\mathrm{n}$, by other words, the companies, for which $\mathrm{n}$ means not age, but life-time. The purpose of this paper is to 
extend BFO theory for this case and compare the results, obtained for companies as remaining in the market (BFO), as well as retired from the market (BFO2).

\section{MODERN THEORY OF CAPITAL COST AND CAPITAL STRUCTURE BY BRUSOV-FILATOVA- OREKHOVA (BFO THEORY) FOR COMPANIES,} WHICH CEASED TO EXIST AT THE TIME MOMENT N

The BFO theory allows as well examine the financial status of the companies which ceased to exist, i.e. of those for which $n$ means not age, but a lifetime, i.e. the time of existence. A lot of schemes of termination of activities of the company can exist: bankruptcy, merger, acquisition, etc. These different schemes require consideration of different boundary conditions for the "residual capitalization" of the company, for "residual debt value" etc. Below we consider one of those schemes, when the value of the debt capital $D$ becomes zero at the time of termination of activity of company $\mathrm{n}$ : in this case the BFO theory requires minimal upgrades, showed below.

From the formula for the capitalization of the company

$V=C F\left[1-(1+W A C C)^{-n}\right] / W A C C$

obtained in BFO theory (Brusov et al. 2015; 2011a,b,c,d,e; 2012 a,b; 2013 a,b,c; 2014 a,b; Filatova et al. 2008), it is easy to get an estimation for the "residual capitalization" of the company, discounted to the time moment $\mathrm{k}$

$V_{k}=\sum_{t=k+1}^{n} \frac{C F}{(1+W A C C)^{t}}=\frac{C F}{W A C C}\left[1-(1+W A C C)^{-(n-k)}\right]$

Using the formula, describing the connection of "residual capitalization" of the company $V_{k}$ and "residual debt value" $D_{k}$

$V_{k}=w_{d} D_{k}$

(note that here debt fraction $w_{d}$ and $V_{k}$ depend on the leverage level $\mathrm{L}$, while $D_{k}$ does not) we obtain an expression for the tax shield for $n$ years subject to the termination of the activities of the company at the moment $\mathrm{n}$

$$
T S_{n}=t k_{d} w_{d} \sum_{k=1}^{n} \frac{V_{k-1}}{\left(1+k_{d}\right)^{k}}=\frac{t k_{d} w_{d} C F}{W A C C} \sum_{k=1}^{n} \frac{1-(1+W A C C)^{-(n-k+1)}}{\left(1+k_{d}\right)^{k}}=
$$

$$
=\frac{t k_{d} w_{d}}{W A C C}\left[\frac{1-\left(1+k_{d}\right)^{-n}}{k_{d}}-\frac{\left(1+k_{d}\right)^{-n}-(1+W A C C)^{-n}}{W A C C-k_{d}}\right] .
$$

Substituting this expression into the equation

$V_{L}=V_{0}+(T S)_{n}$,

which is the generalization of Modigliani - Miller theorem in the presence of corporate taxes for the case of finite time, one gets the equation (let us call it BFO-2)

$$
\begin{aligned}
& \frac{1-(1+W A C C)^{-n}}{W A C C}=\frac{1-\left(1+k_{0}\right)^{-n}}{k_{0}} \\
& +\frac{t k_{d} w_{d}}{W A C C}\left[\frac{1-\left(1+k_{d}\right)^{-n}}{k_{d}}-\frac{\left(1+k_{d}\right)^{-n}-(1+W A C C)^{-n}}{W A C C-k_{d}}\right]
\end{aligned}
$$

from which one can find the WACC for companies with arbitrary lifetime $\mathrm{n}$, provided that the company ceases to function at the time moment $n$.

\section{APPLICATION OF FORMULA BFO-2} form

Formula BFO-2 (6) in MS Excel takes a following

$\left(\left(1-(1+\mathrm{C} 4)^{\wedge}(-\mathrm{H} 4)\right) / \mathrm{C} 4\right)-\left(\left(\left(1-(1+\mathrm{D} 4)^{\wedge}(-\mathrm{H} 4)\right) /\right.\right.$

$\mathrm{D} 4)+\left(\left(\left(\mathrm{G} 4^{\star} \mathrm{E} 4^{\star} \mathrm{F} 4\right) / \mathrm{C} 4\right)^{\star}\left(\left(\left(1-(1+\mathrm{E} 4)^{\wedge}(-\mathrm{H} 4)\right) / \mathrm{E} 4\right)-\right.\right.$

$\left.\left.\left.\left(\left((1+\mathrm{E} 4)^{\wedge}(-\mathrm{H} 4)-(1+\mathrm{C} 4)^{\wedge}(-\mathrm{H} 4)\right) /(\mathrm{C} 4-\mathrm{E} 4)\right)\right)\right)\right)=0$

Using it we get the following results for dependence of WACC on leverage level $L$, lifetime $n$ and on tax on profit rate t (Figures 1, 2 and $\mathbf{3}$ ).

WACC(L)

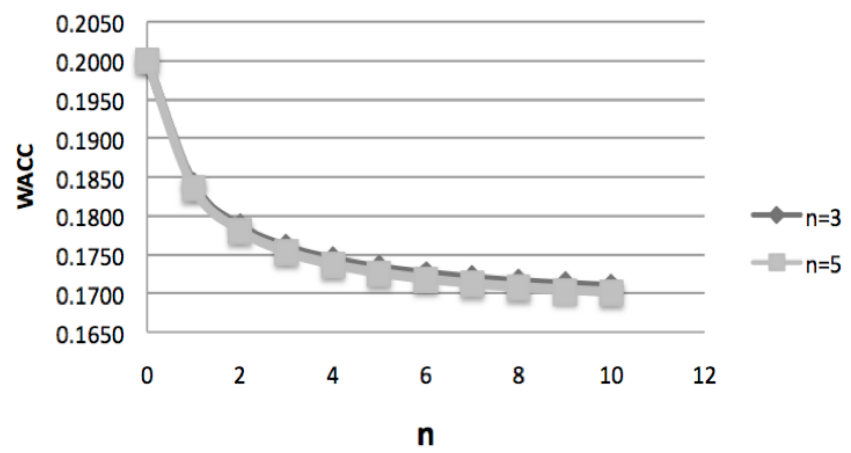

Figure 1: The dependence of the WACC on leverage level L for $\mathrm{n}=3$ and $\mathrm{n}=5 ; k_{0}=0.2 ; k_{d}=0.15$.

\section{COMPARISON OF RESULTS OBTAINED FROM FORMULAS BFO AND BFO-2}

Let us compare results obtained from formulas BFO (Brusov et al. 2015; 2011a,b,c,d,e; 2012 a,b; 2013 a,b,c; 2014 a,b; Filatova et al. 2008) 
WACC(n)

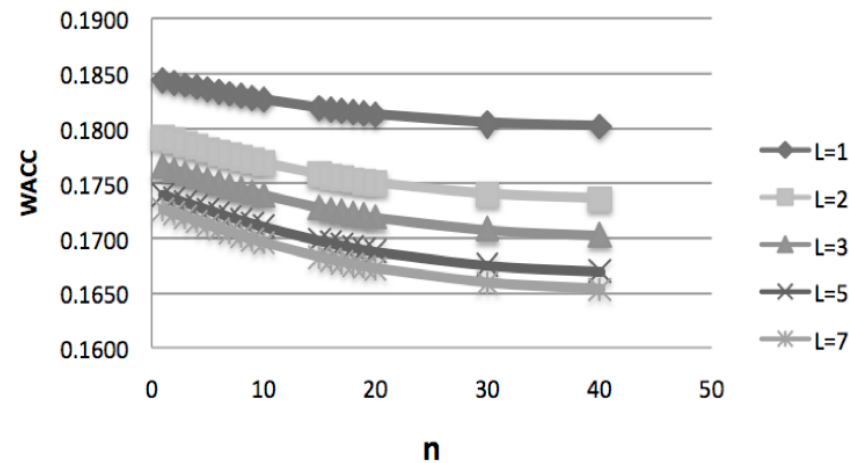

Figure 2: The dependence of the WACC on lifetime $n$ at different leverage level L.

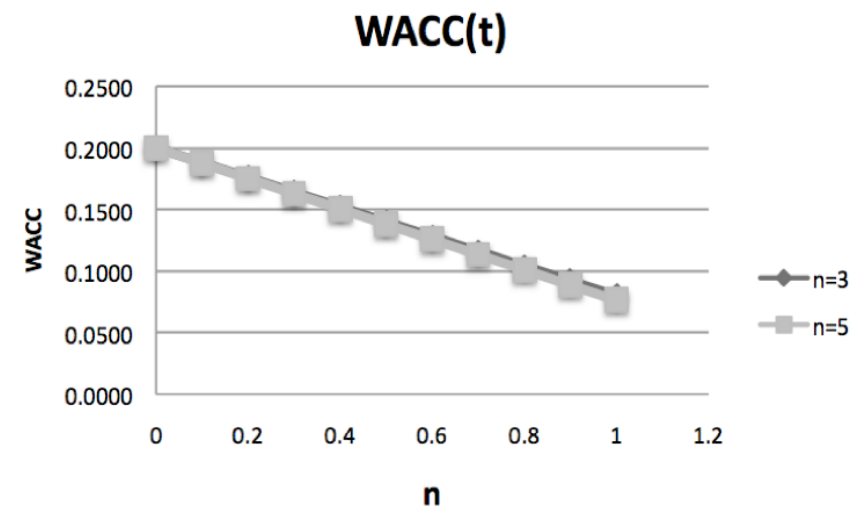

Figure 3: The dependence of the WACC on tax on profit rate $\mathrm{t}$ for $\mathrm{n}=3$ and $\mathrm{n}=5 ; k_{0}=0.2 ; k_{d}=0.15$.

$\frac{1-(1+W A C C)^{-n}}{W A C C}=\frac{1-\left(1+k_{0}\right)^{-n}}{k_{0}\left[1-\omega_{d} T\left(1-\left(1+k_{d}\right)^{-n}\right)\right]}$

and BFO-2 (Formula 6)

$$
\begin{aligned}
& \frac{1-(1+W A C C)^{-n}}{W A C C}=\frac{1-\left(1+k_{0}\right)^{-n}}{k_{0}} \\
& +\frac{t k_{d} w_{d}}{W A C C}\left[\frac{1-\left(1+k_{d}\right)^{-n}}{k_{d}}-\frac{\left(1+k_{d}\right)^{-n}-(1+W A C C)^{-n}}{W A C C-k_{d}}\right]
\end{aligned}
$$

(Figures 4-7).

Comparison of results obtained from formulas BFO and BFO-2 shows that WACC values (at the same values of other parameters) turn out to be higher for the companies which ceased to exist at the time moment $n$, than for companies which have reached the age of $n$ years and continue to exist on the market. By other words the companies, which ceased to exist at the time moment $\mathrm{n}$, attracted a capital (during their lifetime) at higher rate, than for companies which have reached the age of $n$-years and continue to exist on the market.
WACC(L)

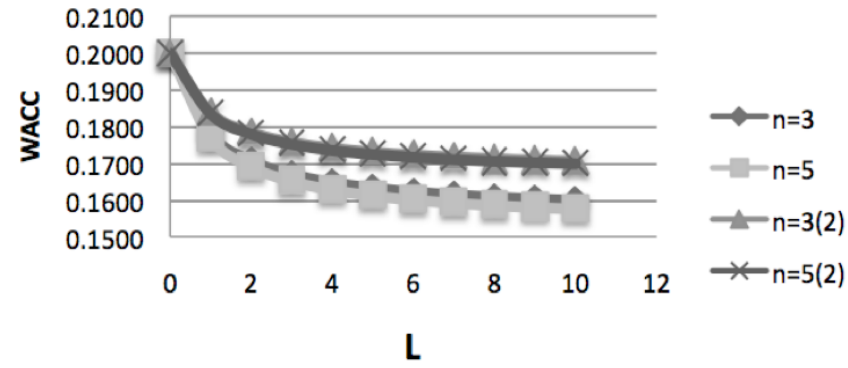

Figure 4: Comparison of the dependence of the WACC on leverage level $L$ for $n=3$ and $n=5$ from formulas $B F O$ and BFO-2.

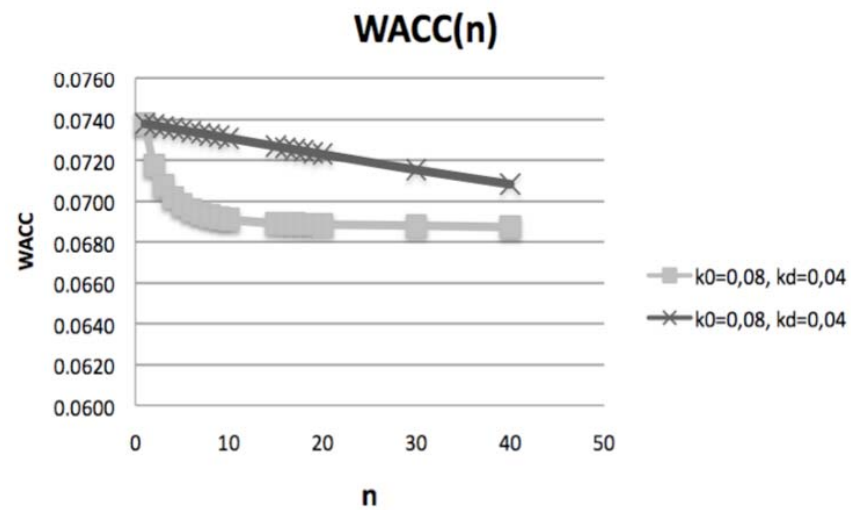

Figure 5: Comparison of the dependence of the WACC on lifetime $\mathrm{n}$ from formulas BFO (lower curve) and BFO-2 (upper curve); $k_{0}=0.08 ; k_{d}=0.04$.

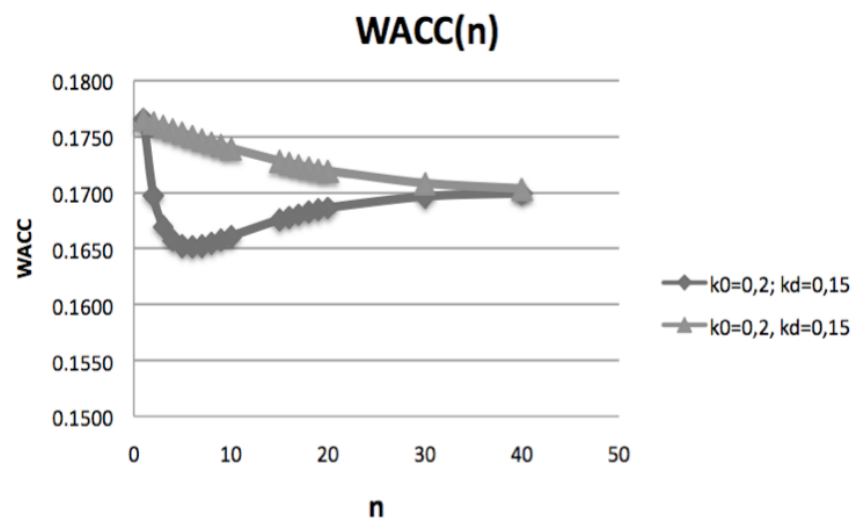

Figure 6: Comparison of the dependence of the WACC on lifetime $\mathrm{n}$ from formulas BFO (lower curve) and BFO-2(upper curve); $k_{0}=0.2 ; k_{d}=0.15 ; \mathrm{L}=3$.

\section{WHETHER THE EFFECTS DISCOVERED BY AUTHORS WITHIN CLASSICAL BFO THEORY ARE PRESENT IN ITS MODIFIED FORM (BFO-2)}

Below we examine whether the effects discovered by authors within classical BFO theory (Brusov et al. 2013 b,c) are present in its modified form (BFO-2). Among a lot of mentioned effects we will study just two ones: 


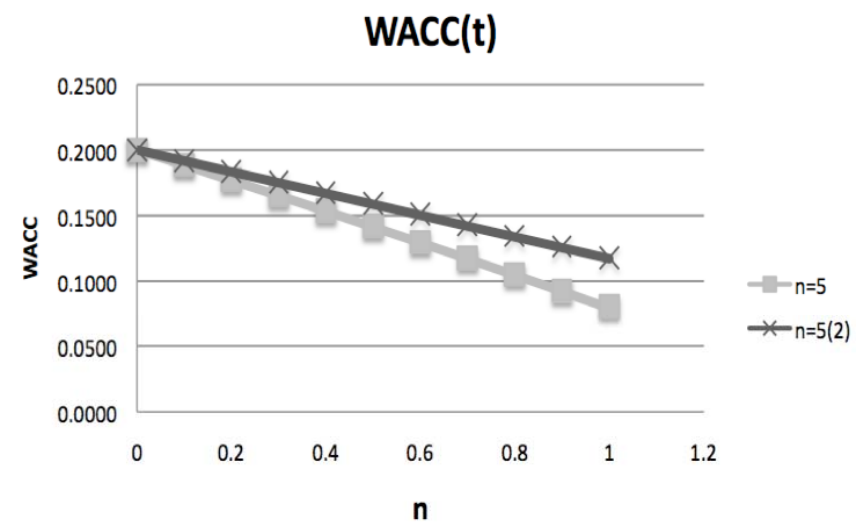

Figure 7: Comparison of the dependence of the WACC on tax on profit rate $t$ from formulas BFO (lower curve) and BFO2 (upper curve); $k_{0}=0.2 ; k_{d}=0.15 ; \mathrm{n}=5$.

1) we examine whether the qualitatively new effect in corporative finance (decreasing of equity cost $k_{e}$ with leverage $\mathrm{L}$ ), existing within classical BFO theory, and which is absent in case of perpetuity companies, takes place for the companies which ceased to exist at the time moment $n$.

2) we check whether the trade off theory, which insolvency has been proved by the authors, is valid for the companies which ceased to exist at the time moment $n$.

The presence of other effects discovered by authors within classical BFO theory within its modified form (BFO-2) will be examined somewhere also.

\subsection{Whether the Qualitatively New Effect in} Corporative Finance (Decreasing of Equity Cost $k_{e}$ with Leverage $L$ ) Takes Place for the Companies which Ceased to Exist at the Time Moment $\mathbf{n}$

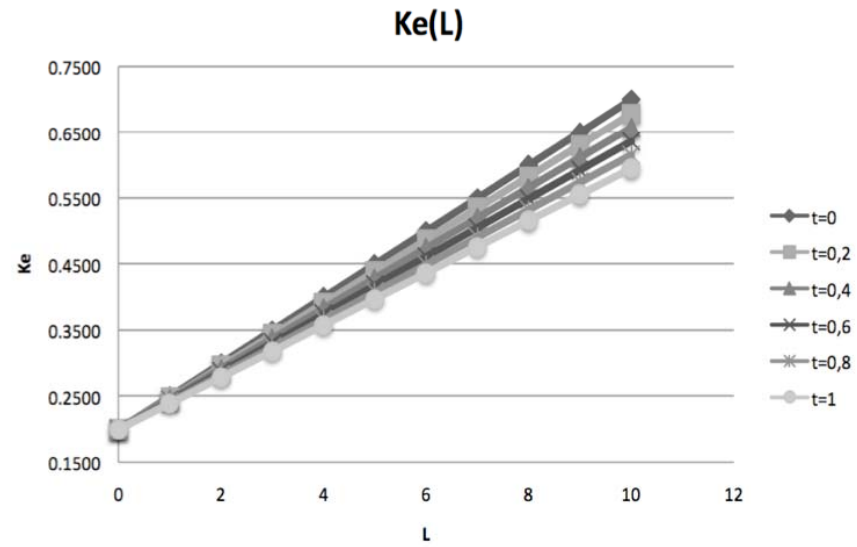

Figure 8: The dependence of the equity cost $k_{e}$ on leverage level $\mathrm{L}$ at different tax on profit rate $t$ from formula BFO-2.

From Figures 8-15 it follows, that the qualitatively new effect in corporative finance: abnormal dependence of equity cost of company on leverage level, which is present in classical BFO theory (Brusov P Filatova T Orehova N (2013c)), is absent in BFO-2 modification (for the companies which ceased to exist at the time moment $n$ ). From this point of view companies which ceased to exist at the time moment $\mathrm{n}$ are similar to perpetuity companies, where this effect is absent as well.

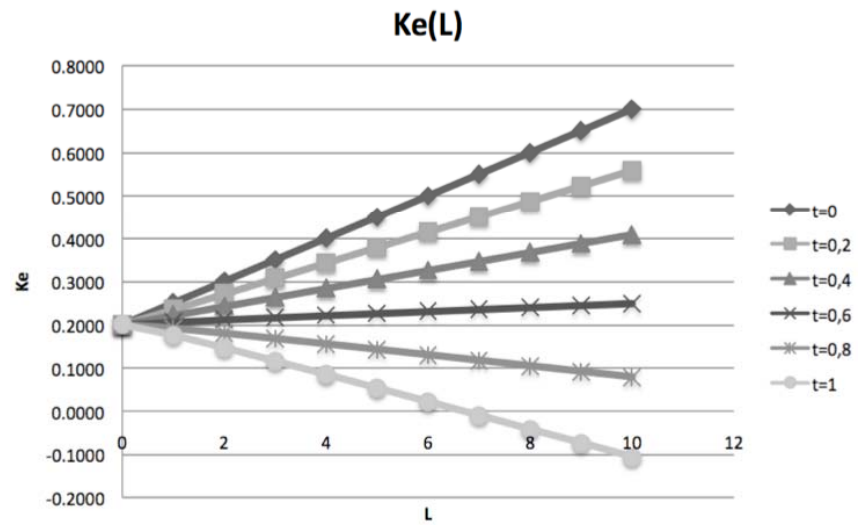

Figure 9: The dependence of the equity cost $k_{e}$ on leverage level $L$ at different tax on profit rate $t$ from formula BFO.

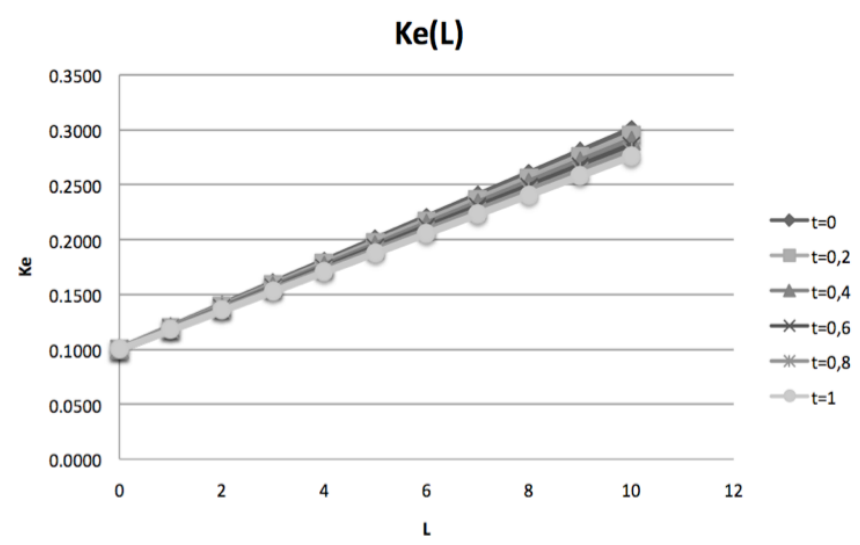

Figure 10: The dependence of the equity cost $k_{e}$ on leverage level $\mathrm{L}$ at different tax on profit rate $\mathrm{t}$ from formula BFO-2.

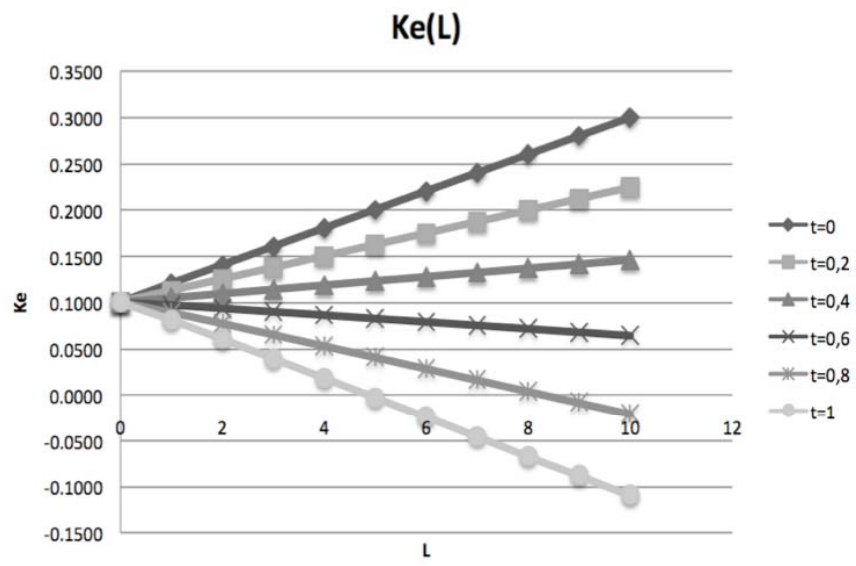

Figure 11: The dependence of the equity cost $k_{e}$ on leverage level $L$ at different tax on profit rate $t$ from formula BFO. 
$\operatorname{Ke}(\mathrm{L})$

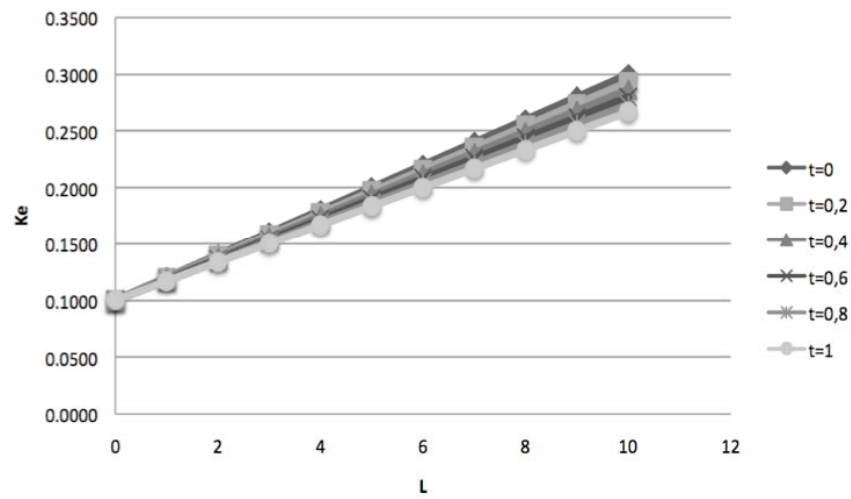

Figure 12: The dependence of the equity cost $k_{e}$ on leverage level $\mathrm{L}$ at different tax on profit rate $\mathrm{t}$ from formula BFO-2.

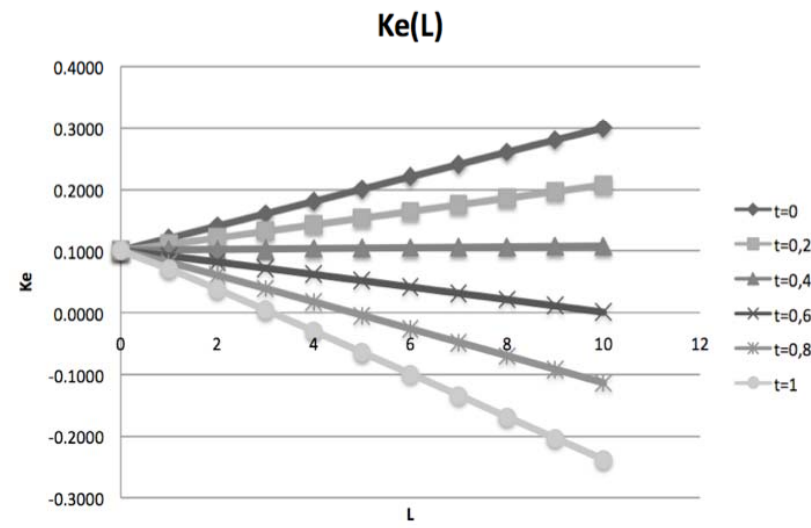

Figure 13: The dependence of the equity cost $k_{e}$ on leverage level $\mathrm{L}$ at different tax on profit rate $t$ from formula BFO.

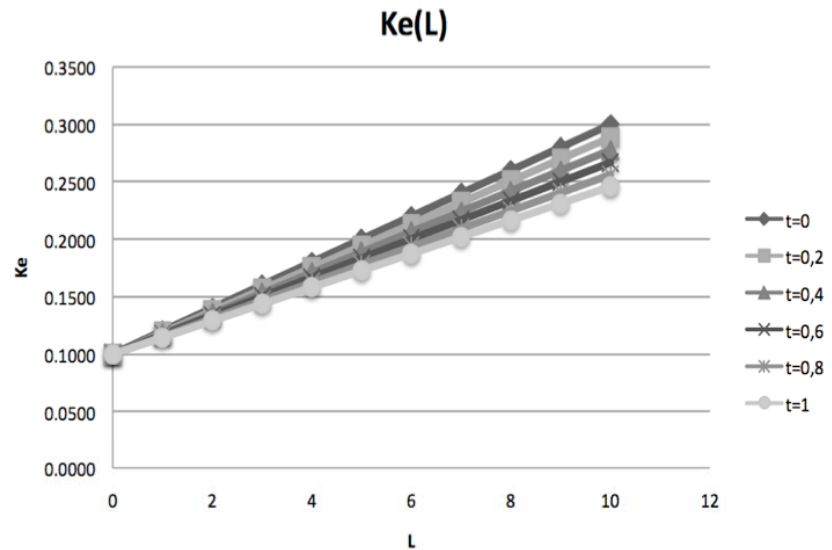

Figure 14: The dependence of the equity cost $k_{e}$ on leverage level $\mathrm{L}$ at different tax on profit rate $t$ from formula BFO-2.

5.2. Whether the Trade Off Theory, which Insolvency has been Proved by the Authors, is Valid for the Companies which Ceased to Exist at the Time Moment $\mathbf{n}$

Below we study the dependence of weighted average cost of capital, WACC, on leverage level L (in
5.2.1) and the dependence of the equity cost $k_{e}$ on leverage level $\mathrm{L}$ from formula BFO-2 in order to clarify whether the famous trade off theory is valid within BFO-theory, modified for the case of companies, which ceased to exist at the time moment $n$. We will use formula BFO-2 (6).

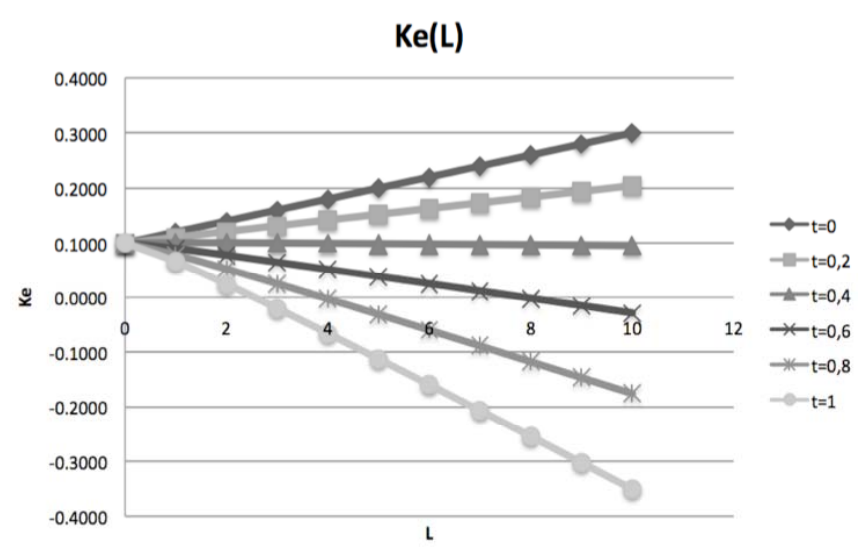

Figure 15: The dependence of the equity cost $k_{e}$ on leverage level $L$ at different tax on profit rate $t$ from formula BFO.

\subsubsection{The Dependence of Weighted Average Cost of Capital, WACC, on Leverage Level $L$ from Formula BFO-2}

We will consider different particular cases 1-8 (linear and quadratic dependence of debt cost on leverage). Note, that as it has been shown in (Brusov P, Filatova T, Orekhova N (2013b)) the results for other cases (exponential etc) turns out to be qualitatively the same.

1. $n=3 ; t=20 \% ; L=0,1,2, \ldots 10$

$$
k_{0}=24 \% ; \bar{k}_{d}=\left\{\begin{array}{c}
0,07 ; \text { nри } L \leq 2 \\
0,07+0,01(L-2) ; \text { nри } L>2
\end{array}\right\}
$$

2. $n=5 ; t=20 \% ; L=0,1,2, \ldots 10$

$$
k_{0}=24 \% ; \bar{k}_{d}=\left\{\begin{array}{c}
0,07 ; \text { nри } L \leq 2 \\
0,07+0,01(L-2) ; \text { nри } L>2
\end{array}\right\}
$$

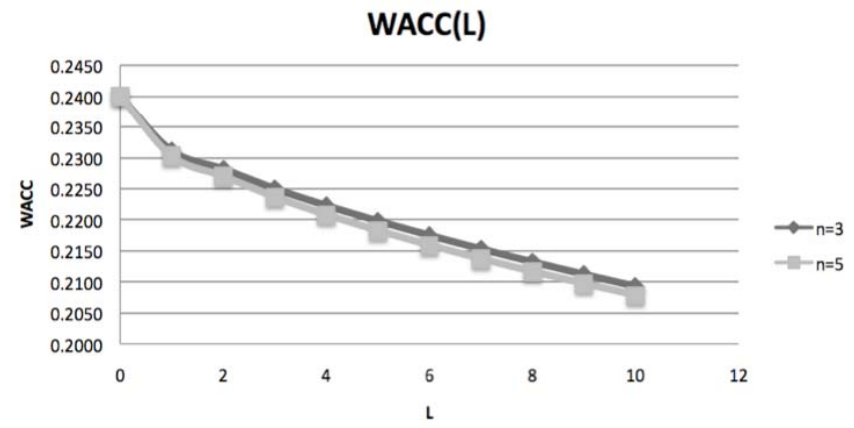

Figure 16: The dependence of weighted average cost of capital, WACC, on leverage level $L$ for $n=3$ and 5 from formula BFO-2. 
3. $n=3 ; t=20 \% ; L=0,1,2, \ldots 10$

$k_{0}=24 \% ; \bar{k}_{d}=\left\{\begin{array}{c}0,07 ; \text { nри } L \leq 2 \\ 0,07+0,1(L-2) ; \text { при } L>2\end{array}\right\}$

4. $n=5 ; t=20 \% ; L=0,1,2, \ldots 10$

$k_{0}=24 \% ; \bar{k}_{d}=\left\{\begin{array}{c}0,07 ; \text { nри } L \leq 2 \\ 0,07+0,1(L-2) ; \text { nрu } L>2\end{array}\right\}$

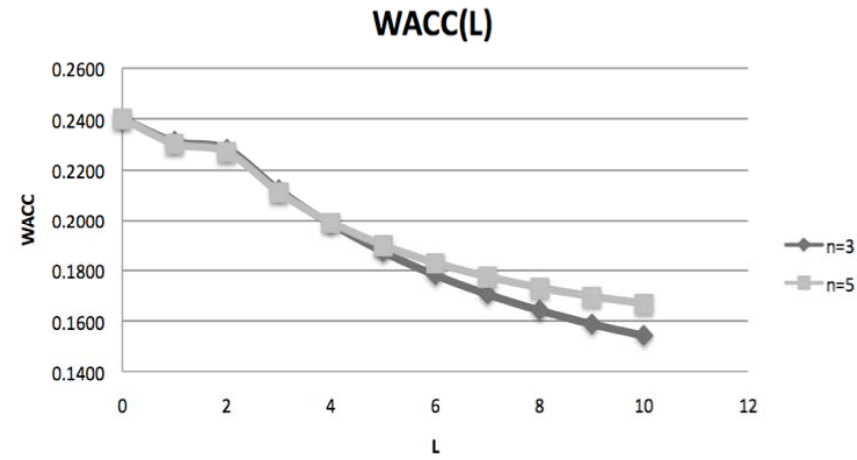

Figure 17: The dependence of weighted average cost of capital, WACC, on leverage level $L$ for $n=3$ and 5 from formula BFO-2.

5. $n=3 ; t=20 \% ; L=0,1,2, \ldots 10$

$k_{0}=12 \% ; \bar{k}_{d}=\left\{\begin{array}{c}0,07 ; \text { nри } L \leq 2 \\ 0,07+0,01(L-2)^{2} ; \text { nри } L>2\end{array}\right\}$

6. $n=5 ; t=20 \% ; L=0,1,2, \ldots 10$

$k_{0}=12 \% ; \bar{k}_{d}=\left\{\begin{array}{c}0,07 ; \text { npu } L \leq 2 \\ 0,07+0,01(L-2)^{2} ; \text { npu } L>2\end{array}\right\}$

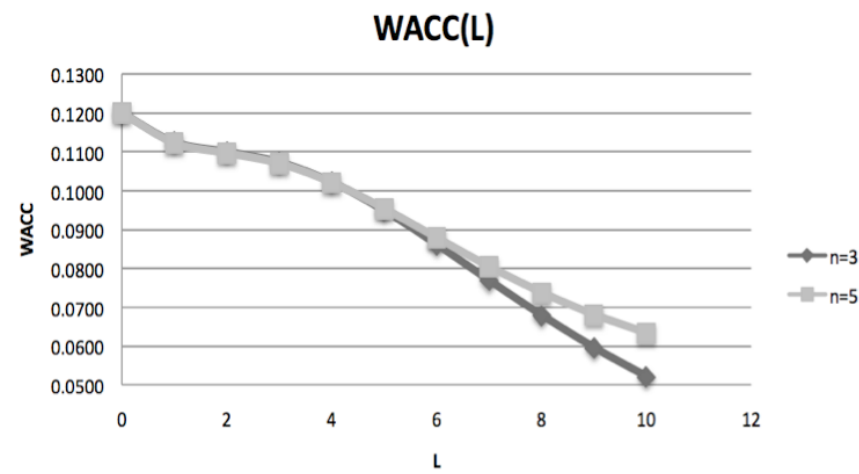

Figure 18: The dependence of weighted average cost of capital, WACC, on leverage level $L$ for $n=3$ and 5 from formula BFO-2.

7. $n=3 ; t=20 \% ; L=0,1,2, \ldots 10$

$k_{0}=12 \% ; \bar{k}_{d}=\left\{\begin{array}{c}0,07 ; \text { nри } L \leq 2 \\ 0,07+0,1(L-2)^{2} ; \text { nри } L>2\end{array}\right\}$
8. $n=5 ; t=20 \% ; L=0,1,2, \ldots 10$

$k_{0}=12 \% ; \bar{k}_{d}=\left\{\begin{array}{c}0,07 ; \text { pрu } L \leq 2 \\ 0,07+0,1(L-2)^{2} ; \text { npu } L>2\end{array}\right\}$

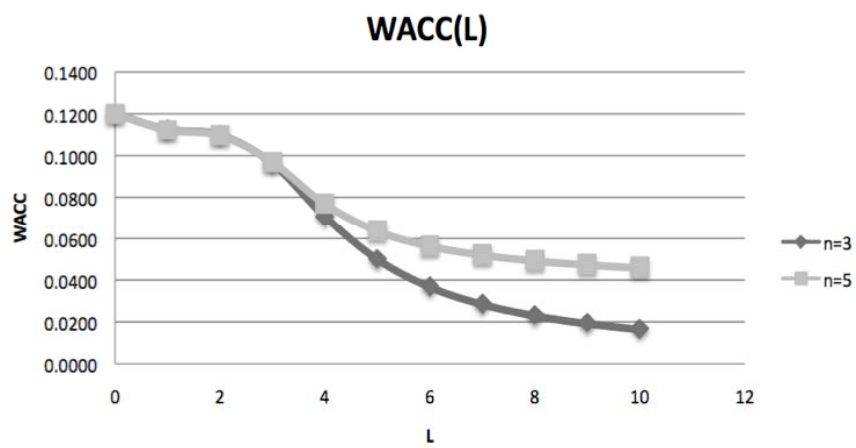

Figure 19: The dependence of weighted average cost of capital, WACC, on leverage level $L$ for $n=3$ and 5 from formula BFO-2.

One can see (Figures 16-19) that WACC $(L)$ is monotonically diminishing function. In spite of the fact, that the rise in the cost of debt financing was assumed, and fairly significant, WACC is not growing with leverage.

In dependence of WACC $(\mathrm{L})$ a cupped zone (in the mathematical sense, $W_{A C C}{L^{2}}^{\prime}<0$ ) appears only, which more or less corresponds to the leverage level, at which the increase in the cost of debt capital begins (in our case, $L=2$ ).

Note that distortion of the WACC $(\mathrm{L})$ dependence is mostly determined by the function $k_{d}(L)$ (linear or quadratic) and by the factors at $(L-2)$ or $(L-2)^{2}$. Linear dependence of $k_{d}(L)$ distorts the WACC $(\mathrm{L})$ dependence less than square one, as well as the smaller factor $(0,01)$.

The change of the company life-time (from 3 to 5 years), has a smaller effect, although a bigger life-times may lead to a more substantial changes in WACC $(\mathrm{L})$ dependence. The reduction of a difference $k_{0}-k_{d}$ between $k_{0}$ and $k_{d}$ leads to an increase of effect.

The main conclusion that can be drawn from the obtained results is the following: the optimal capital structure in well-known "trade off" theory is missing, contrary to hopes and expectations of its creators and supporters.

The question immediately appears: why this turned out to be possible, and how this can be? How can the weighted average cost of capital WACC, which from the definition is equal to 
$W A C C=w_{e} k_{e}+w_{d} k_{d}(1-T)$,

not grow, if both $k_{d}$ and $k_{e}$ are growing ( $k_{e}$ is growing with leverage in accordance to both MM and BFO theory and $k_{d}$ is growing in accordance to our assumption)?

The answer will be received in the next paragraph, where we are investigating the dependence of equity cost $k_{e}$ on leverage $L$ with the same assumptions about the risky of debt capital and growth, as a consequence, of its cost with the leverage. And the answer will be the same as in case of classical BFO theory (Brusov et al. 2013b).

5.2.2. The Dependence of the Equity Cost $k_{e}$ on Leverage Level $L$ from Formula BFO-2

We will consider the same particular cases 1-8 (linear and quadratic dependence of debt cost on leverage), as in 5.2.1. Knowing WACC we calculate the equity cost $k_{e}$, using formula

$k_{e}=W A C C(1+L)-k_{d} L(1-t)$,

which could be easily obtained from the definition of WACC (9)

$W A C C=k_{e} w_{e}+k_{d} w_{d}(1-t)=k_{e} \frac{1}{1+L}+k_{d} \frac{L}{1+L}(1-t)$.

Here, $S$ - the value of equity capital of the company, $w_{d}=\frac{D}{D+S}-$ the share of debt capital; $k_{e}, w_{e}=\frac{S}{D+S}-$ the cost and the share of the equity capital of the company, $L=D / S-$ financial leverage.

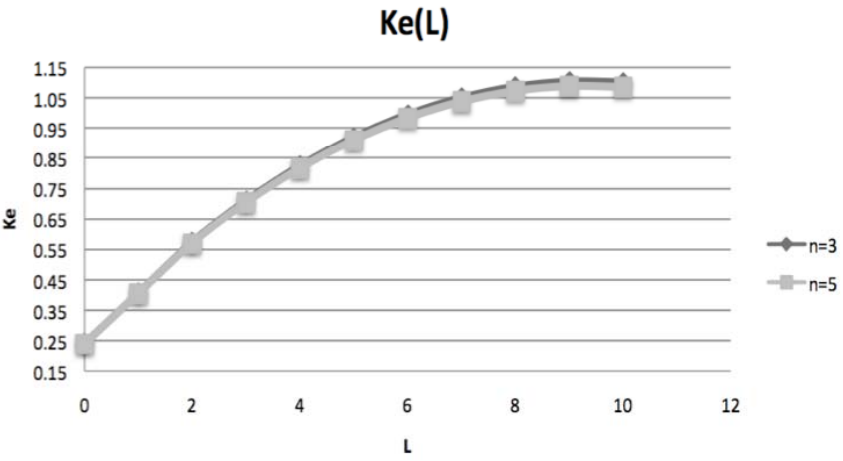

Figure 20: The dependence of the equity cost $k_{e}$ on leverage level $L$ for $n=3$ and 5 from formula BFO-2 (case 1 2).

An analysis of the obtained results (Figures 20-23) leads to the following conclusions.

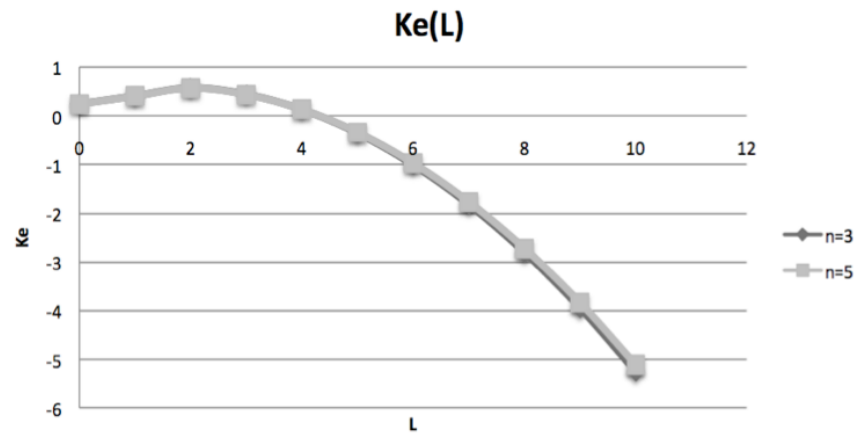

Figure 21: The dependence of the equity cost $k_{e}$ on leverage level $\mathrm{L}$ for $\mathrm{n}=3$ and 5 from formula BFO-2 (case 3$4)$.

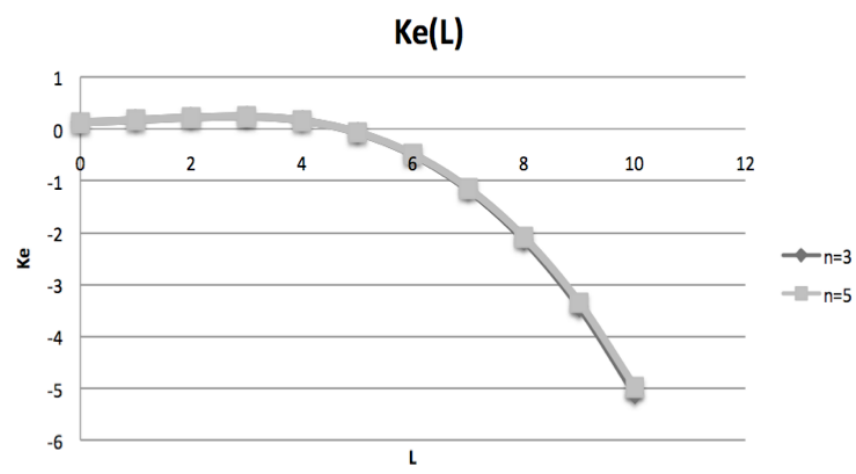

Figure 22: The dependence of the equity cost $k_{e}$ on leverage level $\mathrm{L}$ for $\mathrm{n}=3$ and 5 from formula BFO-2 (case 5 $6)$.

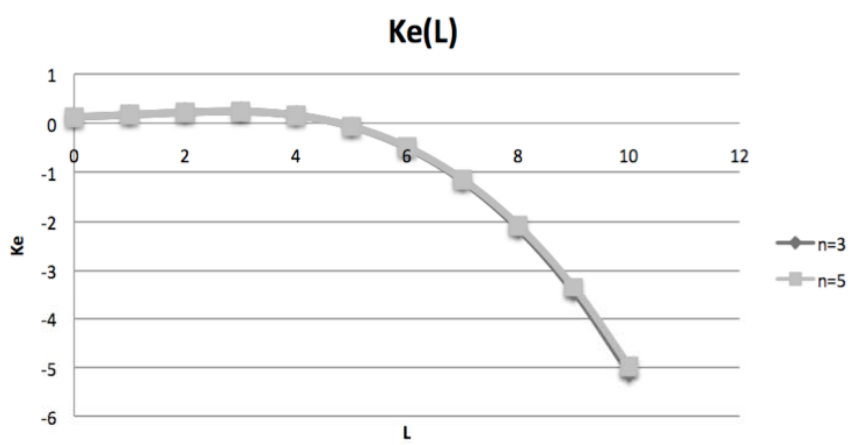

Figure 23: The dependence of the equity cost $k_{e}$ on leverage level $\mathrm{L}$ for $\mathrm{n}=3$ and 5 from formula BFO-2 (case 12).

Under the turning on the growth of debt cost $k_{d}$ with leverage, the dependence of equity cost $k_{e}$ on leverage is undergoing significant changes. The linear growth of equity cost $k_{e}$ at low leverage level is changed by its fall, starting with some value $L_{0}$. The $L_{0}$ value sometimes exactly correlates with the starting point of $k_{d}$ growth with leverage $\left(L_{0}=2\right)$, but sometimes takes values which are significantly higher. 
The speed of decreasing of equity cost $k_{e}$ with leverage increases with increasing of growth factor of debt cost $k_{d}$ as well as under the transition to quadratic growth.

So, we come to the conclusion, that the increase in the cost of debt capital $k_{d}$ with leverage leads to the decrease of equity cost $k_{e}$ with leverage, starting with some value $L_{0}$. This is the cause of the absence of weighted average capital cost growth with leverage at all its values.

So, we have found that within trade off theory there is no an optimal capital structure for BFO-2 case as well as for BFO (Brusov et al. 2013 b). This means that there is no chance of surviving the famous in past the trade off theory.

\section{CONCLUSIONS}

Modern theory of capital cost and capital structure by Brusov-Filatova-Orekhova (BFO theory) (Brusov et al. 2015a), which describes the companies of arbitrary age $\mathrm{n}$ in opposite to the perpetuity Modigliani - Miller theory (Modigliani et al. 1958; 1963; 1966), is applied for companies, which ceased to exist at the time moment $\mathrm{n}$. The required modification of BFO theory has been done in the paper. Formula BFO-2 for calculation of dependences of weighted average cost of capital, WACC, on the company's of lifetime n, on leverage level $L$ and on tax on profit rate $t$ for companies, which ceased to exist at the time moment $n$ has been derived. We analyze these dependences and compare them with the results of classical BFO theory which describes the companies of arbitrary age $n$. Comparing of results, obtained for companies as remaining in the market (BFO), as well as retired from the market (BFO-2) shows that dependence of the weighted average cost of capital WACC of companies on leverage level $L$, the company's lifetime (or age) $n$ and the tax on profit rate $t$ are qualitatively similar in nature, while, there are significant quantitative differences in these dependences: WACC for companies ceased to exist, always turns out to be higher than that of the companies that remain on the market (with the same parameters: leverage level L, the company's lifetime (or age) $\mathrm{n}$ and the tax on profit rate $t$, capital costs (equity and debt)), by other words the cost of attracting capital for companies that continue to operate, is always lower.

It can be explained in a following way: the tax shield value for companies, which ceased to exist at the time moment $\mathrm{n}$ turns out to be lower than that of the companies of age $n$, which remain on the market. The lower value of the tax shield for companies, which ceased to exist leads to higher value of attracting capital for these companies and consequently to lower value of capitalization of them.

We examine whether the effects, discovered by us within classical BFO theory, are present in its modified form (BFO-2). We have found that within trade off theory there is no an optimal capital structure for BFO2 case as well as for BFO. This means that there is no chance of surviving the famous in past the trade off theory.

At the same time the qualitatively new effect in corporative finance (decreasing of equity cost $k_{e}$ with leverage $L$ ), existing within classical BFO theory, is absent in BFO-2 case similar to the case of perpetuity companies.

Concluding, we should tell that companies, which ceased to exist at the time moment $n$, from one side are further from perpetuity companies, than those that remain on the market (WACC for companies ceased to exist, is always higher than that of the companies that remain on the market (described by classical BFO theory), and which, in turn, turns out to be higher, than WACC for perpetuity companies. From other side companies, which ceased to exist are closer to perpetuity companies, because, at least one effect, discovered by us within classical BFO theory (Brusov et al. 2013c), decreasing of equity cost $k_{e}$ with leverage $\mathrm{L}$, is absent in BFO-2 case.

The investigation of companies, which ceased to exist at the time moment $n$, could be useful for business valuation, anti-crises management and other fields.

\section{REFERENCES}

Brusov P, Filatova T, Orehova N, Eskindarov M (2015a), Modern corporate finance, investments and taxation, Springer International Publishing, Switzerland, $373 \mathrm{p}$.

Brusov P, Filatova T, Orehova N, Kulik V (2015b), The golden age of the company (Three colors of company's time), Journal of Reviews on Global Economics 4: 21-42. http://dx.doi.org/10.6000/1929-7092.2015.04.03

Brusov P, Filatova T, Orehova N, Brusova A (2011a) Weighted average cost of capital in the theory of Modigliani-Miller, modified for a finite life-time company. Applied Financial Economics 21(11): 815-824.

http://dx.doi.org/10.1080/09603107.2010.537635

Brusov P, Filatova P, Orekhova N (2013a) Absence of an Optimal Capital Structure in the Famous Tradeoff Theory! Journal of Reviews on Global Economics 2: 94-116. http://dx.doi.org/10.6000/1929-7092.2013.02.8 
Brusov P, Filatova P, Orekhova N (2014a) Mechanism of formation of the company optimal capital structure, different from suggested by trade off theory. Cogent Economics \& Finance 2: $1-13$.

http://dx.doi.org/10.1080/23322039.2014.946150

Brusov P, Filatova T, Orehova N et al. (2011b) From ModiglianiMiller to general theory of capital cost and capital structure of the company. Research Journal of Economics, Business and ICT 2: 16-21.

Brusov P, Filatova T, Eskindarov M, Orehova N (2012a) Influence of debt financing on the effectiveness of the finite duration investment project. Applied Financial Economics 22 (13): 1043-1052. http://dx.doi.org/10.1080/09603107.2011.637893

Brusov P, Filatova T, Orehova $\mathrm{N}$ et al. (2011c) Influence of debt financing on the effectiveness of the investment project within the Modigliani-Miller theory. Research Journal of Economics, Business and ICT (UK) 2: 11-15.

Brusov P, Filatova T, Eskindarov M, Orehova N (2012b) Hidden global causes of the global financial crisis. Journal of Reviews on Global Economics 1: 106-111. http://dx.doi.org/10.6000/1929-7092.2012.01.9

Brusov P.N., Filatova T. V. (2011d) From Modigliani-Miller to general theory of capital cost and capital structure of the company. Finance and credit 435: 2-8.

Brusov P Filatova T Orehova N Brusov P.P Brusova N. (2011e) From Modigliani-Miller to general theory of capital cost and capital structure of the company. Research Journal of Economics, Business and ICT 2: 16-21.

Brusov P Filatova T Orehova N (2014b) Inflation in Brusov-FilatovaOrekhova Theory and in its Perpetuity Limit - Modigliani Miller Theory. Journal of Reviews on Global Economics 3: 175-185.

http://dx.doi.org/10.6000/1929-7092.2014.03.13

P. N. Brusov, T. V. Filatova, N. P. Orekhova, M. A. Eskindarov and V. L. Kulik (2015c) The Role of Taxes and Leverage in the Evaluation of Capital Cost and the Capitalization of the Company, American Journal of Economics, Finance and Management Vol. 1, No. 4.

P. N. Brusov, T. V. Filatova, N. P. Orekhova, I. K. Shevchenko, A.Y. Arkhipov, V. L. Kulik (2015d) Influence of Debt Financing on the Efficiency of Investment Projects. the Analysis of Efficiency of Investment Projects Within the Perpetuity (Modigliani-Miller) Approximation, American Journal of Economics, Finance and Management Vol. 1, No. 4.

P. N. Brusov, T. V. Filatova, N. P. Orekhova, I. K. Shevchenko, A.Y. Arkhipov, V. L. Kulik (2015e) Investment Models with Uniform Debt Repayment and Their Application, American Journal of Economics, Finance and Management Vol. 1, No. 4.

P. N. Brusov, T. V. Filatova, N. P. Orekhova, I. K. Shevchenko, A.Y. Arkhipov, V. L. Kulik (2015e) Whether It Is Possible to Increase of the Investment Efficiency, Increasing Tax on Profit Rate, American Journal of Economics, Finance and Management Vol. 1, No. 4.

Brusov P Filatova T Orehova N (2013c) A Qualitatively New Effect in Corporative Finance: Abnormal Dependence of Cost of Equity of Company on Leverage. Journal of Reviews on Global Economics 2: 183-193. http://dx.doi.org/10.6000/1929-7092.2013.02.15

Filatova T Orehova N Brusova A (2008) Weighted average cost of capital in the theory of Modigliani-Miller, modified for a finite life-time company. Bulletin of the FU 48: 68-77.

Brusova A (2011) A Comparison of the three methods of estimation of weighted average cost of capital and equity cost of company. Financial analysis: problems and solutions 34 (76): 36-42.

Filatova T Orehova N Brusova A (2008) Weighted average cost of capital in the theory of Modigliani-Miller, modified for a finite life-time company. Bulletin of the FU 48: 68-77.

Modigliani F, Miller M (1958) The Cost of Capital, Corporate Finance, and the Theory of Investment. American Economic Review 48: 261-297.

Modigliani F, Miller M (1963) Corporate Income Taxes and the Cost of Capital: A Correction. American Economic Review 53: 147-175.

Modigliani F, Miller M (1966) Some estimates of the Cost of Capital to the Electric Utility Industry 1954-1957. American Economic Review 56: 333-391.

Myers S (1984) The Capital Structure Pussle. Journal of Finance 39(3): 574-592. http://dx.doi.org/10.1111/j.1540-6261.1984.tb03646.x

\section{DOI: http://dx.doi.org/10.6000/1929-7092.2015.04.08}

(c) 2015 Brusov et al.; Licensee Lifescience Global.

This is an open access article licensed under the terms of the Creative Commons Attribution Non-Commercial License (http://creativecommons.org/licenses/by-nc/3.0/) which permits unrestricted, non-commercial use, distribution and reproduction in any medium, provided the work is properly cited. 